\title{
PENGEMBANGAN RENCANA PELAKSANAAN PEMBELAJARAN MATEMATIKA KURIKULUM 2013 BERBASIS LESSON STUDY DI SMP
}

\author{
Sutama, Sabar Narimo, dan Samino \\ Magister Administrasi Pendidikan Sekolah Pascasarjana \\ Universitas Muhammadiyah Surakarta \\ sutama@ums.ac.id
}

\begin{abstract}
The purpose of research, describe and test the development of lesson plan Junior High School math curriculum-based lesson study in 2013. This type of research, namely research and development. The subject of research, math teachers, principals, and students from Junior High School 26 Salatiga, as well as education experts and policy makers. Methods of data collection, observation, interviews, documentation, testing, and questionnaires. Data were analyzed using qualitative analysis flow models, comparison, and test. Result: the planning of the implementation of learning methods section, learning activities, and part of the cover varies greatly from one teacher to another. In the method of a teacher who wrote approach, learning strategies, and learning methods; but there is also a write down approach, a model of learning and teaching methods. The learning activities are structured in a math teacher lesson plan through three stages: preliminary activities, core activities, and closing activity. At each step of the variation of teacher is very diverse, but not pay attention to individual differences of students. At the closing, the teacher with students either individually or in groups do not reflect to evaluate the entire range of activities hereinafter find direct benefit aupun indirectly from the learning outcomes, provide feedback on the learning process and results, conduct follow-up activity in the form of duties, either individually or in groups, and inform future learning plans.
\end{abstract}

Keywords: diverse, individual differences, reflection, variation

\begin{abstract}
Abstrak. Tujuan penelitian, mendeskripsikan dan menguji pengembangan Rencana Pelaksanaan Pembelajaran matematika Sekolah Menengah Pertama kurikulum 2013 berbasis lesson study. Jenis penelitian, yaitu penelitian dan pengembangan. Subjek penelitian, guru matematika, kepala sekolah, dan siswa dari 26 Sekolah Menengah Pertama Kota Salatiga, serta ahli pendidikan dan pengambil kebijakan. Metode pengumpulan data, observasi, wawancara, dokumentasi, tes, dan angket. Teknik analisis data menggunakan analisis kualitatif model alur, komparasi, dan uji t. Hasil penelitian: pada perencanaan pelaksanaan pembelajaran bagian metode, kegiatan pembelajaran, dan bagian penutup sangat bervariasi antara guru satu dengan yang lain. Pada metode ada guru yang menuliskan pendekatan, strategi pembelajaran, dan metode pembelajaran; namun ada juga yang menuliskan pendekatan, model pembelajaran, dan metode pembelajaran. Kegiatan pembelajaran yang disusun guru matematika dalam Rencana Pelaksanaan Pembelajaran melalui tiga tahap, yaitu: kegiatan pendahuluan, kegiatan inti, dan kegiatan penutup. Pada masingmasing langkah tersebut variasi guru sangat beragam, namun belum memperhatikan perbedaan individual siswa. Pada kegiatan penutup, guru bersama siswa baik secara
\end{abstract}


individual maupun kelompok belum melakukan refleksi untuk mengevaluasi seluruh rangkaian aktivitas untuk selanjutnya secara bersama menemukan manfaat langsung aupun tidak langsung dari hasil pembelajaran, memberikan umpan balik terhadap proses dan hasil pembelajaran, melakukan kegiatan tindak lanjut dalam bentuk tugas, baik individual maupun kelompok, dan menginformasikan rencana pembelajaran selanjutnya.

Kata kunci: beragam, perbedaan individual, refleksi, variasi

\section{Pendahuluan}

Sesungguhnya tidak ada kurikulum yang sempurna, karena kurikulum hanya baik dan cocok di jamannya. Perubahan kurikulum sebagai upaya ke arah peningkatan kualitas pendidikan, karena di era globalisasi sangat dituntut adanya Sumber Daya Manusia (SDM) yang memiliki keunggulan kompetitif dan komparatif sesuai standar mutu nasional dan internasional. Orientasi pendidikan bukan hanya pada pengembangan SDM (human resources development), tetapi juga pada pengembangan kapabilitas manusia (human capability development). Kurikulum 2013 merupakan upaya pemerintah agar pendidikan di Indonesia tidak tertinggal dan dapat mengejar kemajuan negara lain.

Rangkaian panjang pengembangan Kurikulum 2013 tahun ajaran 2013/2014 telah memasuki tahap implementasi bertahapterbatas. Untuk tingkat SMP, Kurikulum 2013 telah diimplementasikan di kelas VII pada 1.437 sekolah yang tersebar di 295 Kabupaten/ Kota di seluruh Indonesia. Kurikulum 2013 akan diterapkan secara serentak pada setiap sekolah tahun 2014/2015. Sekolah Menengah Pertama (SMP) di Kota Salatiga Jawa Tengah Tahun 2013/2014 yang menjadi sekolah sasaran penerapan kurikulum 2013 ada enam SMP dari 26 SMP. Hasil observasi pendahuluan, ditemukan kesenjangan penerapan kurikulum 2013, yaitu sebagian besar guru matematika SMP sasaran di Kota Salatiga 1) belum optimal dalam menyusun Rencana Pelaksanaan Pembelajaran (RPP), 2) dalam mengajar cenderung hanya berorientasi pada buku, abstrak, jenis permasalahan belum menyeluruh dan tidak menantang, dan 3) kesulitan dalam melaksanakan penilaian pada aspek sikap dan keterampilan. Kesenjangan tersebut dapat berdampak pada penurunan efektivitas pembelajaran matematika di SMP.

Menurut Sutama (2011: 28-32), proses pembelajaran matematika tidak efektif dikarenakan, metode pembelajaran monoton, suasana tidak menyenangkan, siswa tidak tertarik dengan apa yang disampaikan oleh guru. Guru sebagian besar belum memahami standar isi, kurang mampu dalam mengembangkan silabus dan materi pokok, serta guru kesulitan dalam merumuskan indikator. Guru dalam mengajar masih berorientasi kepada buku, abstrak, dan masih sedikit guru yang menghubungkan materi ajar dengan kehidupan sehari-hari siswa.

Faktor lain yang juga berpengaruh pada proses pembelajaran matematika siswa yaitu motivasi belajar siswa. Majid (2013: 308) mendefinisikan motivasi adalah energi positif yang menyebabkan terjadinya suatu perubahan pada diri seseorang yang tampak pada gejala kejiwaan, perasaan, dan juga emosi sehingga mendorong individu untuk bertindak atau melakukan sesuatu dikarenakan adanya tujuan, kebutuhan, atau keinginan yang harus terpuaskan. Hal tersebut menunjukkan bahwa motivasi merupakan energi penggerak dari setiap kegiatan yang akan dikerjakan sehingga hasil kegiatan tersebut dapat maksimal. Hasil kegiatan yang maksimal berbanding lurus terhadap hasil belajar matematika yang optimal. Realitasnya 
guru tidak mengetahui kondisi awal siswa sehingga guru kurang bisa memotivasi siswa untuk belajar.

Kemandirian belajar juga dimungkinkan memberi warna terhadap proses pembelajaran matematika. Menurut Indarti (2014) kemandirian belajar adalah dorongan kuat dalam diri siswa untuk mewujudkan keinginan secara nyata tanpa bergantung pada orang lain. Dorongan kuat yang dimaksud yaitu kemauan siswa sendiri, pilihan sendiri, tanggung jawab sendiri tanpa bantuan orang lain dan mampu mempertanggungjawabkan tindakannya, serta mampu melakukan aktivitas belajar secara mandiri. Melalui kemandirian belajar, siswa diarahkan untuk berpikir dan bertindak serta mampu mengarahkan dan mengendalikan dirinya sendiri.

Bertolak dari pemikiran di atas dan dalam kondisidarurat "segeramengimplementasikan kurikulum 2013", seyogyanya guru memfokuskan pada pengelolaan pembelajaran dengan strategi sesuai kebutuhan, yaitu mengembangkan pembelajaran matematika kurikulum 2013 berbasis lesson study. Pembelajaran matematika kurikulum 2013 dengan pendekatan scientific, sehingga dapat merangsang wawasan anak dalam rangka merespon lingkungan. Lesson study merupakan model pembinaan profesi pendidik melalui pengkajian pembelajaran secara kolaboratif dan berkelanjutan berlandaskan prinsip-prinsip kolegialitas mutual learning untuk membangun komunitas belajar(Sutama, Narimo, dan Haryoto, 2013). Hal ini sesuai dengan prinsip pelaksanaan kurikulum 2013, yakni siswa harus mendapatkan pelayanan pendidikan yang bermutu, serta memperoleh kesempatan untuk mengekspresikan dirinya secara bebas, dinamis, dan menyenangkan.

Bagaimana realitasnya di lapangan? Ada kesan umum, kemampuan guru matematika dalam implementasi kurikulum 2013 masih berpredikat sebagai pelaksana kurikulum dan bahkan kegiatan yang mereka lakukan lebih bersifat rutinitas. Guru belum siap menghadapi berbagai perubahan, akses pada materi mutakhir terbatas, wawasan dan keterampilan pembelajaran juga terbatas. Pembelajaran yang mereka laksanakan kering dan tanpa makna. Matematika yang disajikan kepada para siswa hanyalah kumpulan angkaangka dan rumus-rumus yang membosankan, tidak ada penanaman nilai-nilai (value) yang sangat berguna untuk pembentukan sikap dan kepribadian yang lengkap (utuh). Pembentukan sikap disiplin, sikap teliti, sikap kritis, sikap sabar, sikap hati-hati, sikap peduli, sikap berani dan sikap adil belum dikembangkan melalui matematika. Para siswa tidak mengetahui untuk apa belajar matematika. Lebih menyedihkan lagi, bukubuku paket dijadikan guru sebagai sumber utama untuk penilaian hasil belajar.

Menurut Martino dan Zan (2009) membangun sikap belajar matematika harus dilakukan oleh guru kepada siswa dalam pembelajaran. Sikapmemilikiperanan penting untuk guru dan siswa dalam pembelajaran. Li dan Yu (2009) mengemukakan, bahwa seorang guru matematika yang menggunakan pengetahuan pedagogic untuk mengajar matematika dapat untuk membangun sikap belajar. Hansson (2010) memberikan arahan agar pembelajaran efektif, yaitu a) guru melakukan penawaran kondisi yang sesuai untuk belajar matematika kepada siswa, b) siswa membangun pengetahuan matematika mereka sendiri, c) keberadaan isi matematika yang relevan memungkinkan guru untuk memberikan materi secara penuh atau siswa membangun pengetahuan dan sikap mereka sendiri. Berdasarkan pendapat para ahli ini, dapat dimaknai bahwa pembelajaran matematika akan bermakna dan menyenangkan apabila siswa diberi kesempatan untuk mengembangkan potensinya dengan fasilitator guru yang profesional.

Secara umum, tujuan penelitian ini yaitu, mendeskripsikan pengelolaan pembelajaran matematika kurikulum 2013 yang dilakukan guru SMP Kota Salatiga Jawa Tengah. 
Adapun secara rinci artikel ini memaparkan pengembangan RPP matematika SMP kurikulum 2013 berbasis lesson study.

\section{Metode}

Jenis penelitian berdasarkan pendekatannya Penelitian dan Pengembangan. Penelitian dan Pengembangan (Research and Development) adalah suatu proses untuk mengembangkan produk yang telah ada dan dapat dipertanggung jawabkan (Sutama, 2012: 183). Pelaksanaan penelitian ini menggunakan metode deskriptif, evaluatif, dan eksperimen.

Penelitian dilakukan di 26 SMP Kota Salatiga Jawa Tengah. Semua SMP untuk eksplorasi data awal, delapan SMP sebagai tempat ujicoba dan 16 SMP lainnya sebagai tempat implementasi model pembelajaran yang dikembangkan. Subjek penelitian, guru matematika, kepala sekolah, dan siswa dari 26 SMP Kota Salatiga Jawa Tengah. Subjek penenelitian lainnya, yaitu ahli pendidikan, dan pengambil kebijakan. Pejabat di Disdikpora Salatiga (Kasubdin dan pengawas) dan Kepala SMP Kota Salatiga mewakili subjek penelitian pengambil kebijakan. Subjek penelitian yang mewakili ahli pendidikan dipilih ahli metode dan strategi pembelajaran, ahli pengembangan model pembelajaran, dan person yang memiliki keahlian pendidikan matematika

Teknik pengumpulan dengan metode observasi, wawancara, dokumentasi, tes, dan angket (Denzin dan Lincoln, 2009: 495). Teknik analisis data menggunakan analisis kualitatif model alur (Flick, Kardorff, and Steinke, 2004: 266), komparasi dan uji t (Gall, Gall, and Borg, 2003: 402).

\section{Hasil dan Pembahasan}

Perencanaan pembelajaran dirancang dalam bentuk Silabus dan Rencana Pelaksanaan Pembelajaran (RPP) yang mengacu pada Standar Isi. Perencanaan pembelajaran meliputi penyusunan rencana pelaksanaan pembelajaran dan penyiapan media dan sumber belajar, perangkat penilaian pembelajaran, dan skenario pembelajaran. Penyusunan Silabus dan RPP disesuaikan pendekatan pembelajaran yang digunakan. Selanjutnya hasil penelitian ini difokuskan pada RPP yang disusun guru matematika tempat penelitian.

RPP adalah rencana kegiatan pembelajaran tatap muka untuk satu pertemuan atau lebih. RPP dikembangkan dari silabus untuk mengarahkan kegiatan pembelajaran siswa dalam upaya mencapai Kompetensi Dasar(KD). Setiap pendidik pada satuan pendidikan berkewajiban menyusun RPP secara lengkap dan sistematis agar pembelajaran berlangsung secara interaktif, inspiratif, menyenangkan, menantang, efisien, memotivasi peserta didik untuk berpartisipasi aktif, serta memberikan ruang yang cukup bagi prakarsa, kreativitas, dan kemandirian sesuai dengan bakat, minat, dan perkembangan fisik serta psikologis siswa. RPP disusun berdasarkan KD atau subtema yang dilaksanakan dalam satu kali pertemuan atau lebih.

Sistematika RPP yang disusun guru matematika tempat penelitian kompenennya sesuai Peraturan Menteri Pendidikan dan Kebudayaan Republik Indonesia Nomor 65 Tahun 2013 Tentang Standar Proses Pendidikan Dasar dan Menengah. Kompenen RPP yang disusun guru matematika disampaikan berikut.

Komponen RPP terdiri dari: 1) identitas sekolah yaitu nama satuan pendidikan, 2) identitas mata pelajaran atau tema/subtema, 3) kelas/semester, 4) materi pokok, 5) alokasi waktu ditentukan sesuai dengan keperluan untuk pencapaian KD dan beban belajar dengan mempertimbangkan jumlah jam pelajaran yang tersedia dalam silabus dan $\mathrm{KD}$ yang harus dicapai, 6) tujuan pembelajaran yang dirumuskan berdasarkan $\mathrm{KD}$, dengan menggunakan kata kerja operasional yang dapat diamati dan diukur, yang mencakup sikap, pengetahuan, dan keterampilan, 7) kompetensi dasar dan indikator pencapaian kompetensi, 8) materi pembelajaran, memuat fakta, konsep, prinsip, dan prosedur yang 
relevan, dan ditulis dalam bentuk butir-butir sesuai dengan rumusan indikator ketercapaian kompetensi, 9) metode pembelajaran, digunakan oleh pendidik untuk mewujudkan suasana belajar dan proses pembelajaran agar peserta didik mencapai KD yang disesuaikan dengan karakteristik siswa dan KD yang akan dicapai, 10) media pembelajaran, berupa alat bantu proses pembelajaran untuk menyampaikan materi pelajaran, 11) sumber belajar, dapat berupa buku, media cetak dan elektronik, alam sekitar, atau sumber belajar lain yang relevan, 12) langkah-langkah pembelajaran dilakukan melalui tahapan pendahuluan, inti, dan penutup, dan 13) penilaian hasil pembelajaran.
Penyajian beberapa komponen RPP yang disusun guru matematika pada sekolah tempat penelitian masih beragam. Sebagian guru menuliskan Kompetensi Inti, Kompetensi Dasar, dan Indikator secara naratif namun juga terdapat guru yang menuliskan hal tersebut dalam bentuk tabel. Penulisan secara naratif ada dua versi, yaitu 1) Kompetensi Inti, Kompetensi Dasar, dan Indikator urutan kebawah secara terpisah dan 2) Kompetensi Inti, Kompetensi Dasar dan Indikator urut kebawah tetapi Indikator mengikuti masingmasing Kompetensi Dasar.

Penulisan Kompetensi Inti, Kompetensi Dasar, dan Indikator dalam bentuk tabel dapat diperiksa pada tabel 1 berikut.

Tabel 1 Penulisan Kompetensi Inti, Kompetensi Dasar, dan Indikator Bentuk Tabel

\begin{tabular}{|c|c|c|}
\hline Kompetensi Inti & Kompetensi Dasar & Indikator \\
\hline $\begin{array}{l}\text { 1. Menghargai dan menghayati ajaran agama } \\
\text { yang dianutnya }\end{array}$ & $\begin{array}{l}\text { Menghargai dan } \\
\text { menghayati ajaran agama } \\
\text { yang dianutnya }\end{array}$ & $\begin{array}{l}\text { 1.1.1 Berdoa sebelum } \\
\text { memulai pelajaran }\end{array}$ \\
\hline $\begin{array}{l}\text { Menghargai dan menghayati perilaku jujur, } \\
\text { disiplin, tanggung jawab, peduli (toleransi, } \\
\text { gotong royong), santun, percaya diri, dalam } \\
\text { berinteraksi secara efektif dengan lingkungan } \\
\text { sosial dan alam dalam jangkauan pergaulan } \\
\text { dan keberadaannya }\end{array}$ & $\begin{array}{l}\text { Menunjukkan sikap logis, } \\
\text { kritis, analitik, konsisten } \\
\text { dan teliti, bertanggung } \\
\text { jawab, responsif dan tidak } \\
\text { mudah menyerah dalam } \\
\text { memecahkan masalah. }\end{array}$ & $\begin{array}{l}\text { Menunjukkan rasa ingin } \\
\text { tahu dalam melakukan } \\
\text { penyelidikan tentang } \\
\text { operasi bentuk aljabar } \\
\text { 2.1.2Bertanggungjawab } \\
\text { dalam kelompok } \\
\text { belajarnya; }\end{array}$ \\
\hline $\begin{array}{l}\text { Memahami pengetahuan (faktual, } \\
\text { konseptual, dan prosedural) berdasarkan rasa } \\
\text { ingin tahunya tentang ilmu pengetahuan, } \\
\text { teknologi, seni, budaya terkait fenomena dan } \\
\text { kejadian tampak mata }\end{array}$ & $\begin{array}{l}\text { Menerapkan operasi aljabar } \\
\text { yang melibatkan bilangan } \\
\text { rasional. }\end{array}$ & $\begin{array}{l}\text { 3.1.1.Memahami perkalian } \\
\text { bentuk aljabar; } \\
\text { 3.1.2.Menentukan hasil } \\
\text { perkalian bentuk aljabar }\end{array}$ \\
\hline $\begin{array}{l}\text { Mencoba, mengolah, dan menyajikan dalam } \\
\text { ranah konkret (menggunakan, mengurai, } \\
\text { merangkai, memodifikasi, dan membuat) } \\
\text { dan ranah abstrak (menulis, membaca, } \\
\text { menghitung, menggambar, dan mengarang) } \\
\text { sesuai dengan yang dipelajari di sekolah dan } \\
\text { sumber lain yang sama dalam sudut pandang/ } \\
\text { teori }\end{array}$ & $\begin{array}{l}\text { 4.1 Membuat dan } \\
\text { menyelesaikan model } \\
\text { matematika dari masalah } \\
\text { nyata yang berkaitan } \\
\text { dengan persamaan linear } \\
\text { dua variabel. }\end{array}$ & $\begin{array}{l}\text { Menggunakan perkalian } \\
\text { bentuk aljabar untuk } \\
\text { menyelesaikan masalah } \\
\text { nyata dalam kehidupan } \\
\text { sehari-hari }\end{array}$ \\
\hline
\end{tabular}


Penyajian komponen Kompetensi Inti, Kompetensi Dasar, dan Indikator tersebut mempunyai alasan masing-masing, namun secara sederhana untuk memaknai keterkaitan dan keterpaduan antara KI, KD, dan indikator pencapaian kompetensi, ada baiknya penyajian ditampilkan dalam bentuk tabel. Tampilan dalam tabel lebih menguntungkan, karena konsistensi penjabaran dari yang lebih umum menjadi lebih operasional segera dapat diketahui dan kekurangan maupun bias diantaranya juga segera dapat diketahui.

Penulisan metode pada RPP juga menunjukkan perbedaan diantara guru satu dengan guru yang lain. Pada metode ada guru yang menuliskan pendekatan, strategi pembelajaran, dan metode pembelajaran; namun ada juga yang menuliskan pendekatan, model pembelajaran, dan metode pembelajaran. Contoh informasi ini disajikan pada tabel 2 berikut.

Tabel 2 Perbedaan penulisan metode pada RPP

\begin{tabular}{ll}
\hline \multicolumn{1}{c}{ Guru A } & \multicolumn{1}{c}{ Guru B } \\
\hline Pendekatan : & Pendekatan : Pendekatan \\
Pendekatan Saintifik & Saintifik \\
Strategi pembelajaran & Model pembelajaran : \\
: Pembelajaran & Pembelajaran Penemuan \\
Penemuan (Discovery & (Discovery Learning) \\
Learning) & Metode Pembelajaran: \\
Metode Pembelajaran: & Pengamatan, tanya- \\
Pengamatan, tanya- & jawab, penugasan \\
jawab, penugasan & individu, dan diskusi \\
individu, dan diskusi & kelompok. \\
kelompok. & \\
\hline
\end{tabular}

Berdasarkan informasi tersebut, perbedaan penyebutan model pembelajaran dan strategi pembelajaran dari Discovery Learning dimungkinkan guru hanya ikutikutan dan belum membaca sendiri konsep yang sebenarnya. Selain itu, guru belum memahami perbedaan dari konsep model pembelajaran dan strategi pembelajaran. Berarti lesson study sangat bermakna, karena belajar bersama saling menghargai sangat baik untuk meminimalkan perbedaan persepsi guru tentang konsep model, pendekatan, strategi, metode, teknik, dan taktik pembelajaran.

Pada kegiatan pembelajaran semua guru matematika tempat penelitian cenderung tidak ada variasi yang menyolok, namun aktivitas guru ditulis sangat dominan. Hal ini menunjukkan, bahwa dalam menyusun RPP guru belum memperhatikan prinsip partisipasi aktif siswa dan berpusat pada siswa untuk mendorong semangat belajar, motivasi, minat, kreativitas, inisiatif, inspirasi, inovasi dan kemandirian. Kebiasaan menulis "Guru" terlalu banyak dalam RPP perlu diubah menjadi siswa yang harus mengalami belajar. Pengalaman belajar merupakan wadah bagi siswa untuk mengembangkan kreativitas dan pada gilirannya siswa mampu mencipta.

Kegiatan pembelajaran yang disusun guru matematika tempat penelitian dalam RPP melalui tiga tahap, yaitu: kegiatan pendahuluan, kegiatan inti, dan kegiatan penutup. Pada masing-masing langkah tersebut variasi guru sangat beragam, namun belum memperhatikan perbedaan individual siswa antara lain: kemampuan awal, tingkat intelektual, bakat, potensi, minat, motivasi belajar, kemampuan sosial, emosi, gaya belajar, kebutuhan khusus, kecepatan belajar, latar belakang budaya, norma, nilai, dan/atau lingkungan siswa.

Pada kegiatan pendahuluan, guru satu dengan yang lain masih terdapat variasi dalam menulis menyiapkan siswa secara psikis dan fisik untuk mengikuti proses pembelajaran, motivasi, apersepsi, dan menyampaikan tujuan serta cakupan materi dan penjelasan uraian kegiatan sesuai silabus. Guru sangat dominan ditulis dalam kegiatan pendahuluan dan sangat lemah dalam menuliskan memberikan motivasi dan apersepsi. Begitu juga menulis menyampaikan tujuan serta cakupan materi dan penjelasan uraian kegiatan sesuai silabus, cenderung yang aktif guru. Ini semua karena keterbatasan guru dalam belajar bersama, sehingga guru lupa bahwa dalam penulisan RPP ada baiknya 
menggunakan metode pembelajaran yang mengkaitkan gradasi sikap, pengetahuan, dan keterampilan siswa.

Sebagai contoh dalam kegiatan penandahuluan, pada waktu guru menulis memberi motivasi belajar siswa secara kontekstual sesuai manfaat dan aplikasi materi ajar dalam kehidupan sehari-hari, dengan memberikan contoh dan perbandingan lokal, nasional dan internasional; kebanyakkan guru matematika tempat penelitian hanya menulis "guru memberikan motivasi belajar". Hal ini akan lebih baik apabila dituliskan "melalui pengamatan contoh penayangan vedio, siswa menghayati dan memahami manfaat dan aplikasi materi ajar dalam kehidupan seharihari”. Melalui pengamatan merupakan aspek keterampilan, menghayati merupakan aspek afektif, dan memahami merupakan aspek kemampuan.

Gradasi sikap, pengetahuan, dan keterampilan harus selalu diperhatikan penuh dalam kegiatan inti. Sesuai dengan karakteristik sikap, maka salah satu alternatif yang dipilih adalah proses afeksi mulai dari menerima, menjalankan, menghargai, menghayati, hingga mengamalkan. Seluruh aktivitas pembelajaran berorientasi pada tahapan kompetensi yang mendorong siswa untuk melakuan aktivitas tersebut.
Pengetahuan dimiliki melalui aktivitas mengetahui, memahami, menerapkan, menganalisis, mengevaluasi, hingga mencipta. Karakteritik aktivititas belajar dalam domain pengetahuan ini memiliki perbedaan dan kesamaan dengan aktivitas belajar dalam domain keterampilan. Untuk memperkuat pendekatan saintifik, disarankan untuk menerapkan belajar berbasis penyingkapan/ penelitian (discovery/inquiry learning). Untuk mendorong siswa menghasilkan karya kreatif dan kontekstual, baik individual maupun kelompok, disarankan menggunakan pendekatan pembelajaran yang menghasilkan karya berbasis pemecahan masalah (project based learning).

Keterampilan diperoleh melalui kegiatan mengamati, menanya, mencoba, menalar, menyaji,danmencipta. Seluruhisimateri(topik dan subtopik) matematika yang diturunkan dari keterampilan harus mendorong siswa untuk melakukan proses pengamatan hingga penciptaan. Untuk mewujudkan keterampilan tersebut perlu melakukan pembelajaran yang menerapkan belajar berbasis penyingkapan/ penelitian (discovery/inquirylearning) dan pembelajaran yang menghasilkan karya berbasis pemecahan masalah (project based learning). Rincian gradasi sikap, pengetahuan, dan keterampilan disajikan pada tabel 3.

Tabel 3 Rincian Gradasi Sikap, Pengetahuan, dan Keterampilan

\begin{tabular}{lll}
\hline \multicolumn{1}{c}{ Sikap } & \multicolumn{1}{c}{ Pengetahuan } & \multicolumn{1}{c}{ Keterampilan } \\
\hline Menerima & Mengingat & Mengamati \\
Menjalankan & Memahami & Menanya \\
Menghargai & Menerapkan & Mencoba \\
Menghayati & Menganalisis & Menalar \\
Mengamalkan & Mengevaluasi & Menyaji \\
& & Mencipta \\
\hline
\end{tabular}

Pada kegiatan inti guru matematika pada sekolah tempat penelitian cenderung sesuai dengan pendekatan scientific dan sintak strategi yang digunakan. Semua aspek scientific sudah terencana yaitu: mengamati, menanya, mengumpulkan informasi, mengolah informasi, mengkomunikasikan.
Sintak strategi juga sudah direncanakan, yaitu sebagai contoh proses pembelajaran dengan strategi discovery learning (DL). Fase pertama, pemberian rangsangan; Fase kedua, identifikasi masalah; Fase Ketiga, pengumpulan data, Fase ke-empat pengolan data; Fase kelima, verifikasi data; dan Fase ke- 
enam, menarik kesimpulan. Guru menuliskan pemanfaatan teknologi informasi dan komunikasi secara terintegrasi, sistematis, dan efektif sesuai dengan situasi dan kondisi.

Pada kegiatan penutup ditulis pada RPP oleh guru matematika pada sekolah bervariasi. Ada guru yang membuat rangkuman kemudian memberikan kesan terhadap pengalaman pembelajaran (motivasi). Ada juga guru yang secara sistematis menutup kegiatan pembelajaran dengan membuat rangkuman, refleksi terhadap kegiatan yang sudah dilakukan, memberikan tugas, dan menyampaikan rencana pembelajaran pada pertemuan berikutnya. Hal ini menunjukkan, bahwa guru matematika tidak fokus dan tidak punya komitmen tinggi dalan menulis RRP.

Dalam kegiatan penutup, ada baiknya guru bersama siswa baik secara individual maupun kelompok melakukan refleksi untuk mengevaluasi: 1) seluruh rangkaian aktivitas pembelajaran dan hasil-hasil yang diperoleh untuk selanjutnya secara bersama menemukan manfaat langsung aupun tidak langsung dari hasil pembelajaran yang telah berlangsung, 2) memberikan umpan balik terhadap proses dan hasil pembelajaran, 3) melakukan kegiatan tindak lanjut dalam bentuk pemberian tugas, baik tugas individual maupun kelompok, dan 4) menginformasikan rencana kegiatan pembelajaran untuk pertemuan berikutnya.

\section{Penutup}

Setelah dilakukan pengembangan
rencana pelaksanaan matematika SMP Kurikulum 2013 berbasis lesson study maka perlu dilakukan uji efektivitas. Pada perencanaan pelaksanaan pembelajaran bagian metode, kegiatan pembelajaran, dan bagian penutup sangat bervariasi antara guru satu dengan yang lain. Pada metode ada guru yang menuliskan pendekatan, strategi pembelajaran, dan metode pembelajaran; namun ada juga yang menuliskan pendekatan, model pembelajaran, dan metode pembelajaran.

Kegiatan pembelajaran yang disusun guru matematika tempat penelitian dalam
RPP melalui tiga tahap, yaitu: kegiatan pendahuluan, kegiatan inti, dan kegiatan penutup. Pada masing-masing langkah tersebut variasi guru sangat beragam, namun belum memperhatikan perbedaan individual siswa. Pada kegiatan penutup, guru bersama siswa baik secara individual maupun kelompok cenderung belum melakukan refleksi untuk mengevaluasi: 1) seluruh rangkaian aktivitas pembelajaran dan hasilhasil yang diperoleh untuk selanjutnya secara bersama menemukan manfaat langsung aupun tidak langsung dari hasil pembelajaran yang telah berlangsung, 2) memberikan umpan balik terhadap proses dan hasil pembelajaran, 3) melakukan kegiatan tindak lanjut dalam bentuk pemberian tugas, baik tugas individual maupun kelompok, dan 4) menginformasikan rencana kegiatan pembelajaran untuk pertemuan berikutnya.

Berbagai ucapan terima kasih kami sampaikan kepada berbagai pihak yang telah menyukseskan kegiatan penelitian ini. Ucapan terima kasih kami sampaikan kepada DIKTI DP2M dan KOPERTIS Wilayah VI yang telah membantu dalam pendanaan biaya penelitian multi tahun melalui Hibah Penelitian Tim Pascasarjana. Ucapan terima kasih kami sampaikan kepada Direktur Sekolah Pascasarjana dan Ketua Lembaga Penelitian UMS beserta stafnya, yang telah memberikan fasilitas dan dorongan sehingga kami bisa melakukan penelitian. ucapan terima kasih juga kami sampaikan kepada kepala DIKPORA, para kepala dan guru matematika SMP Kota Salatiga Jawa Tengah, yang telah membantu proses penelitian sehingga berjalan sesuai perencanaan.

Berbagai ucapan terima kasih kami sampaikan kepada berbagai pihak yang telah mendukung kegiatan penelitian ini. Ucapan terima kasih kami sampaikan kepada Direktorat Riset dan Pengabdian Masyarakat Direktorat Jenderal penguatan Riset dan Pengembangan Kementerian Riset, Teknologi, dan pendidikan Tinggi yang telah membantu dalam pendanaan biaya penelitian multi tahun melalui Hibah 
Penelitian Tim Pascasarjana. Ucapan terima kasih kami sampaikan kepada Direktur Sekolah Pascasarjana dan Ketua Lembaga Penelitian UMS beserta stafnya, yang telah memberikan fasilitas dan dorongan sehingga kami bisa melakukan penelitian. ucapan terima kasih juga kami sampaikan kepada kepala DIKPORA, para kepala dan guru matematika SMP Kota Salatiga Jawa Tengah, yang telah membantu proses penelitian sehingga berjalan sesuai perencanaan.

\section{Daftar Pustaka}

Denzin, N.K. \& Lincoln, Y. S. 2009. Handbook of Qualitative Research (Edisi Bahasa Indonesia). Yogyakarta: Pustaka Pelajar.

Gall, M.D., Gall, J.P., and Borg, W.R. 2003. Educational Research An Introduction. New York: Pearson Educational, Inc.

Hansson, A. 2010.'Instructional responsibility in mathematics education: modelling classroom teaching using Swedish data". Educational Studies in Mathematics May 2010, vol. 7(5), $171-189$.

Indarti, S. M. (Eds.). (2014). Prosiding Seminar Nasional Pendidikan Matematika 2014: Peran Kemampuan Komunikasi dan Berpikir Kritis Matematis serta Kemandirian Belajar Siswa SMA Menggunakan Pendekatan Pembelajaran Berbasis Masalah. Sekolah Tinggi Keguruan dan Ilmu Pendidikan (STKIP) Siliwangi Bandung: Program Pascasarjana Pendidikan Matematika.

Li, M. and Yu P. 2009. "Study on Effect of Mathematics Teachers' Pedagogical Content Knowledge on Mathematics Teaching”. Journal of Mathematic Education, Juni 2009, Vol.2,No.1, 55-68.

Majid, A. (2013). Strategi Pembelajaran. Bandung: PT Remaja Rosdakarya.

Martino, P. D. and Zan, R. 2009.'Me and maths': towards a definition of attitude grounded on students' narratives".Journal of Mathematic Teacher Education, Vol. 5, No.13, 27-48.

Sutama. 2011. "Pengelolaan Pembelajaran Matematika Berbasis Aptitude Treatment Interaction", Pidato Pengukuhan Guru Besar, Disampaikan pada Sidang Senat Terbuka UMS, Sabtu, 8 Januari 2011.

Sutama. 2012. "Metode Penelitian Pendidikan (Kuantitatif, Kualitatif, PTK, R\&D). Surakarta: Fairuz Media.

Sutama, Narimo, S., dan Haryoto. 2013. "Contextual Math Learning Based on Lesson Study Can Increase Study Communication”. International Journal of Education. Vol. 5, No. 4, 48-60. 